\title{
Winogradskyella poriferorum sp. nov., a novel member of the family Flavobacteriaceae isolated from a sponge in the Bahamas
}

Correspondence Pei-Yuan Qian boqianpy@ust.hk
Stanley C. K. Lau, ${ }^{1}$ Mandy M. Y. Tsoi, ${ }^{1}$ Xiancui Li, ${ }^{1}$ loulia Plakhotnikova, ${ }^{1}$ Sergey Dobretsov, ${ }^{1}$ Ken W. K. Lau, ${ }^{1}$ Madeline Wu, ${ }^{1}$ Po-Keung Wong, ${ }^{2}$ Joseph R. Pawlik ${ }^{3}$ and Pei-Yuan Qian ${ }^{1}$

\author{
${ }^{1}$ Coastal Marine Laboratory/Department of Biology, The Hong Kong University of Science \\ and Technology, Clear Water Bay, Kowloon, Hong Kong, People's Republic of China \\ ${ }^{2}$ Department of Biology, The Chinese University of Hong Kong, Shatin, N.T., Hong Kong, \\ People's Republic of China \\ ${ }^{3}$ Center for Marine Science, University of North Carolina at Wilmington, USA
}

The Cytophaga-Flavobacterium-Bacteroides group, comprising the families Bacteroidaceae, Cytophagaceae, Cryomorphaceae, Flavobacteriaceae, Sphingobacteriaceae and Spirosomaceae, is a main phyletic line within the domain Bacteria (Bernardet et al., 2002; Bowman et al., 2003). Many members of the Flavobacteriaceae have been isolated from the surfaces of marine algae (Nedashkovskaya et al., 2005). Winogradskyella is a recently established genus within the family Flavobacteriaceae (Nedashkovskaya et al., 2005). The three recognized members of Winogradskyella were isolated from algal frond surfaces in the Sea of Japan

Published online ahead of print on 4 March 2005 as DOI 10.1099/ ijs.0.63661-0.

The GenBank/EMBL/DDBJ accession number for the 16S rRNA gene sequence of strain UST030701-295 ${ }^{\top}$ is AY848823.

A scanning electron micrograph of cells of strain UST030701-295 ${ }^{\top}$ and tables detailing the primers used for construction of the 16S rRNA gene sequences and results of carbohydrate metabolism tests are available as supplementary material in IJSEM Online.
(Nedashkovskaya et al., 2005). In this study, we describe a novel member of the genus isolated from the surface of a sponge in tropical water.

During the characterization of bacteria isolated from the surface of the sponge Lissodendoryx isodictyalis in the Bahamas, strain UST030701-295 ${ }^{\mathrm{T}}$ was isolated on an agar medium consisting of $5 \mathrm{~g}$ peptone $\mathrm{l}^{-1}, 3 \mathrm{~g}$ yeast extract $1^{-1}$ and $0 \cdot 22-\mu \mathrm{m}$-filtered seawater (hereafter marine agar) after $48 \mathrm{~h}$ of incubation at $30^{\circ} \mathrm{C}$. Unless otherwise specified, all characteristics described are based on cultures grown on marine agar under these conditions. Cells of strain UST030701-295 ${ }^{\mathrm{T}}$ appeared as yellow, convex, circular colonies (2-4 $\mathrm{mm}$ in diameter) with entire margins and a smooth surface. No diffusible pigment was observed.

The nearly complete $16 \mathrm{~S}$ rRNA gene sequence of UST030701-295 ${ }^{\mathrm{T}}$ (1441 bp) was resolved on a MegaBACE capillary genetic analyser using a dye terminator method according to the manufacturer's protocol. Primers used in the sequencing reactions are given in Supplementary 
Table S1 available in IJSEM Online. Fragments of DNA sequence obtained from individual primers with at least six replicates each were assembled using the Sequencher software package (Gene Codes). Comparison of the $16 \mathrm{~S}$ rRNA gene sequence of strain UST030701-295 ${ }^{\mathrm{T}}$ to those available from GenBank revealed that UST030701-295 represented a member of the family Flavobacteriaceae. Its closest relatives were Winogradskyella epiphytica KMM $3906^{\mathrm{T}}(95 \cdot 8 \% 16 \mathrm{~S}$ rRNA gene sequence similarity), Winogradskyella eximia KMM $3944^{\mathrm{T}}(94 \cdot 7 \%)$ and Winogradskyella thalassocola KMM $3907^{\mathrm{T}}(94 \cdot 7 \%)$ (Nedashkovskaya et al., 2005). A neighbour-joining phylogenetic tree (Fig. 1) constructed using the ARB software package (Ludwig et al., 2004) indicated that UST030701$295^{\mathrm{T}}$ and the three recognized species of Winogradskyella belonged to the same clade. Within this clade, UST030701$295^{\mathrm{T}}$ and $W$. eximia formed a separate branch, which clustered robustly ( $99 \%$ bootstrap support, 500 replicates) with the branch formed by $W$. epiphytica and $W$. thalassocola. Trees based on maximum-parsimony and maximumlikelihood methods showed the same topology. The results of phylogenetic analysis suggest that strain UST030701$295^{\mathrm{T}}$ represents a novel species within the genus Winogradskyella.

The G $+\mathrm{C}$ content of the DNA of UST030701-295 ${ }^{\mathrm{T}}$, as determined by using an HPLC method (Mesbah et al., 1989), was $32 \cdot 8 \pm 0 \cdot 7 \mathrm{~mol} \%$. This value is similar to those described for $W$. epiphytica $(35.2 \mathrm{~mol} \%)$, W. eximia $(36 \cdot 1 \mathrm{~mol} \%)$ and $W$. thalassocola $(34 \cdot 6 \mathrm{~mol} \%)$. The predominant cellular fatty acids of UST030701-295 ${ }^{\mathrm{T}}$ were iso$\mathrm{C}_{15: 1}$, iso- $\mathrm{C}_{15: 0}$, iso- $\mathrm{C}_{15: 0} 2-\mathrm{OH}$, iso- $\mathrm{C}_{15: 0} 3-\mathrm{OH}$, iso- $\mathrm{C}_{16: 0}$
3- $\mathrm{OH}, \mathrm{C}_{16: 1} \omega 7$ and iso- $\mathrm{C}_{17: 0} 3-\mathrm{OH}$ (together representing $75.4 \%$ of the total) as determined using the Sherlock Microbial Identification System according to the manufacturer's protocol. This fatty acid profile is similar to that of the three recognized members of Winogradskyella (Table 1). MK-6 is the only respiratory quinone present, as determined using an HPLC method according to Collins (1994). Menaquinones extracted from Cytophaga lytica (Nakagawa \& Yamasato, 1993) and Sphingobacterium heparinum (Steyn et al., 1998) served as references for MK-6 and MK-7, respectively.

The phenotypic characteristics of UST030701-295 ${ }^{\mathrm{T}}$ are given under the species description below. Anaerobic growth was examined in the Oxoid Anaerobic System. Requirement for $\mathrm{NaCl}$ was tested in a medium containing $5 \mathrm{~g} \mathrm{MgCl}_{2} \mathrm{l}^{-1}, 2 \mathrm{~g} \mathrm{MgSO}_{4} \mathrm{l}^{-1}, 0 \cdot 5 \mathrm{~g} \mathrm{CaCl}_{2} \mathrm{l}^{-1}, 1 \mathrm{~g} \mathrm{KCl}^{-1}$, $5 \mathrm{~g}$ peptone $1^{-1}$ and various amounts of $\mathrm{NaCl}$ adjusted to $\mathrm{pH} 7 \cdot 5$ using $\mathrm{KOH}$ (Isnansetyo \& Kamei, 2003). Cell morphology was examined using scanning electron microscopy (JEOL 7600F) according to the procedures detailed in Neu et al. (2001) (see Supplementary Fig. S1 in IJSEM Online). Reaction to Gram-stain was determined using light microscopy according to the method of Smibert \& Krieg (1994). Gliding motility was determined using phasecontrast light microscopy as described by Bowman (2000). Susceptibility to antibiotics was tested using the method of Acar (1980). Oxidase and catalase activities and the degradation of agar, DNA and starch were tested according to the methods of Smibert \& Krieg (1994). Flexirubin pigment production and cellulose hydrolysis were determined as described by Bowman (2000). Casein hydrolysis

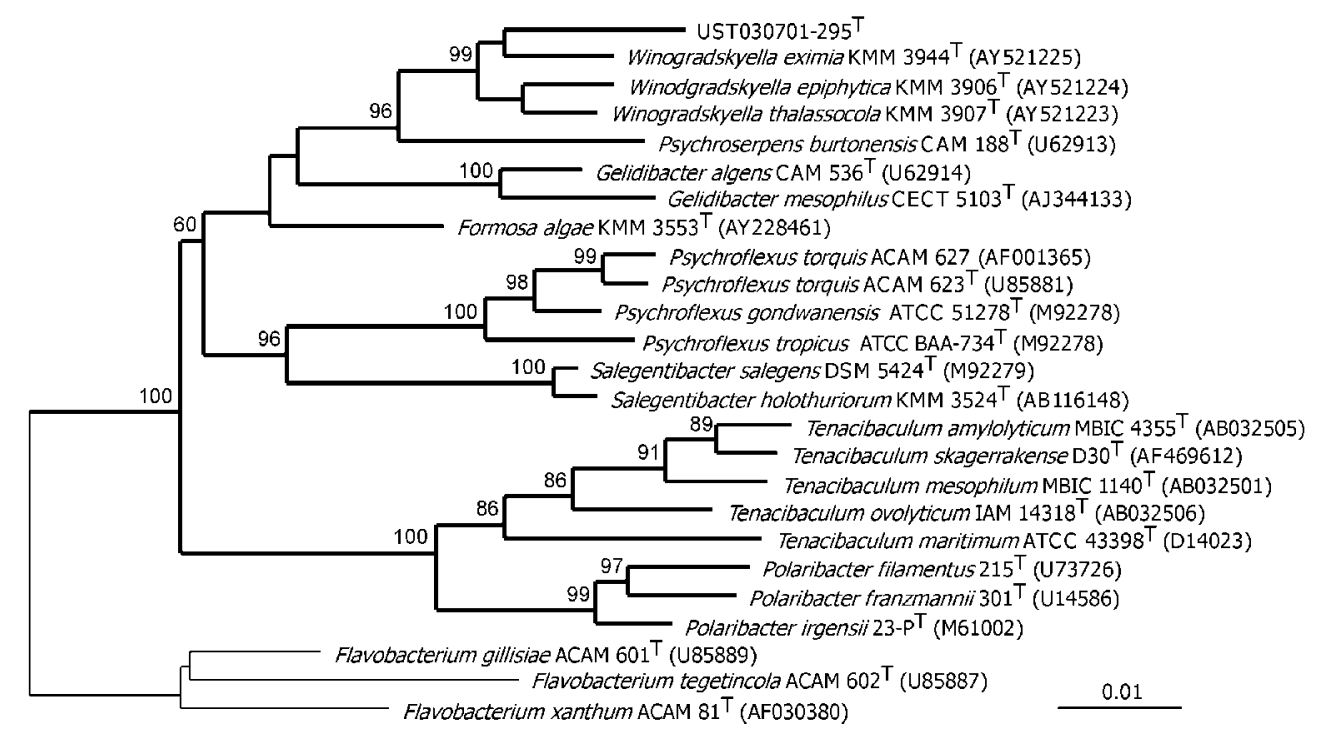

Fig. 1. Unrooted neighbour-joining dendrogram showing the estimated phylogenetic relationships among UST030701-295 ${ }^{\top}$ and related species on the basis of 16S rRNA gene sequences. Strains belonging to the genus Flavobacterium served as outgroups. Lines in bold indicate branches also found in maximum-likelihood and maximum-parsimony trees. Bootstrap values of $>50 \%$ (500 replicates) are indicated at the nodes. The GenBank accession number for each reference strain is shown in parentheses. Bar, 1 nucleotide substitution per 100 nucleotides. 
Table 1. Cellular fatty acid profiles of UST030701-295 ${ }^{\top}$ and previously described members of the genus Winogradskyella

Taxa: 1, UST030701-295 ${ }^{\mathrm{T}}$; 2, W. epiphytica; 3, W. eximia; 4, W. thalassocola. Values given for UST030701-295 ${ }^{\mathrm{T}}$ are mean percentages \pm SD $(n=3)$ of the total fatty acids. Data for $W$. epiphytica, W. eximia and $W$. thalassocola are taken from Nedashkovskaya et al. (2005).

\begin{tabular}{|c|c|c|c|c|}
\hline Fatty acid & 1 & 2 & 3 & 4 \\
\hline iso- $\mathrm{C}_{13: 0}$ & $2 \cdot 6 \pm 0 \cdot 1$ & - & - & - \\
\hline iso- $\mathrm{C}_{14: 0}$ & $1 \cdot 2 \pm 0 \cdot 1$ & $4 \cdot 5$ & $1 \cdot 4$ & $2 \cdot 6$ \\
\hline iso- $\mathrm{C}_{14: 0} 3-\mathrm{OH}$ & $0 \cdot 5 \pm 0 \cdot 1$ & $1 \cdot 6$ & - & $0 \cdot 9$ \\
\hline iso- $\mathrm{C}_{14: 1}$ & $2 \cdot 0 \pm 0 \cdot 3$ & $1 \cdot 4$ & - & - \\
\hline $\mathrm{C}_{15: 0}$ & - & $1 \cdot 2$ & $6 \cdot 7$ & $7 \cdot 9$ \\
\hline anteiso- $\mathrm{C}_{15: 0}$ & - & $15 \cdot 9$ & $7 \cdot 0$ & $4 \cdot 9$ \\
\hline iso- $\mathrm{C}_{15: 0}$ & $12 \cdot 6 \pm 1 \cdot 1$ & $6 \cdot 7$ & $25 \cdot 6$ & $8 \cdot 7$ \\
\hline iso- $\mathrm{C}_{15: 0} 3-\mathrm{OH}$ & $9 \cdot 8 \pm 1 \cdot 0$ & $2 \cdot 9$ & $2 \cdot 6$ & $11 \cdot 9$ \\
\hline $\mathrm{C}_{15: 0} 2-\mathrm{OH}$ & $3 \cdot 1 \pm 0 \cdot 5$ & $3 \cdot 3$ & $1 \cdot 0$ & $1 \cdot 8$ \\
\hline $\mathrm{C}_{15: 0} 3-\mathrm{OH}$ & $2 \cdot 4 \pm 0 \cdot 7$ & - & - & $2 \cdot 5$ \\
\hline $\mathrm{C}_{15: 1} \omega 6$ & - & - & - & $6 \cdot 5$ \\
\hline anteiso- $\mathrm{C}_{15: 1}$ & $1 \cdot 5 \pm 0 \cdot 2$ & $6 \cdot 3$ & $1 \cdot 4$ & $1 \cdot 6$ \\
\hline iso- $\mathrm{C}_{15: 1}$ & $20 \cdot 9 \pm 0 \cdot 6$ & $8 \cdot 1$ & $10 \cdot 4$ & $11 \cdot 4$ \\
\hline iso- $\mathrm{C}_{15: 0} 2-\mathrm{OH} / \mathrm{C}_{16: 1} \omega 7^{\star}$ & $9 \cdot 8 \pm 0 \cdot 8$ & $5 \cdot 1$ & $6 \cdot 1$ & $4 \cdot 2$ \\
\hline $\mathrm{C}_{16: 0}$ 10-methyl & - & - & $6 \cdot 3$ & - \\
\hline $\mathrm{C}_{16: 0} 3-\mathrm{OH}$ & $1 \cdot 3 \pm 0 \cdot 1$ & - & - & $1 \cdot 0$ \\
\hline iso- $\mathrm{C}_{16: 0}$ & $0 \cdot 5 \pm 0 \cdot 2$ & $3 \cdot 7$ & $5 \cdot 7$ & $0 \cdot 8$ \\
\hline iso- $\mathrm{C}_{16: 0} 3-\mathrm{OH}$ & $11 \cdot 43 \pm 0 \cdot 1$ & $17 \cdot 1$ & $3 \cdot 2$ & $18 \cdot 1$ \\
\hline iso- $\mathrm{C}_{16: 1}$ & $0 \cdot 8 \pm 0 \cdot 3$ & $3 \cdot 5$ & $4 \cdot 7$ & $2 \cdot 7$ \\
\hline $\mathrm{C}_{17: 0} 2-\mathrm{OH}$ & $0 \cdot 3 \pm 0 \cdot 0$ & $5 \cdot 2$ & $1 \cdot 0$ & $0 \cdot 8$ \\
\hline $\mathrm{C}_{17: 0} 0$ cyclo & - & - & $2 \cdot 4$ & - \\
\hline iso- $\mathrm{C}_{17: 0} 3-\mathrm{OH}$ & $10 \cdot 2 \pm 0 \cdot 7$ & $7 \cdot 3$ & $6 \cdot 7$ & $5 \cdot 4$ \\
\hline anteiso- $\mathrm{C}_{17: 1}$ & - & - & $2 \cdot 3$ & - \\
\hline iso- $\mathrm{C}_{17: 1} \omega 9$ & - & $1 \cdot 1$ & - & $0 \cdot 6$ \\
\hline $\mathrm{C}_{17: 1} \omega 6$ & $0 \cdot 2 \pm 0 \cdot 1$ & $1 \cdot 9$ & - & $0 \cdot 9$ \\
\hline Unknown & $3 \cdot 9 \pm 0 \cdot 6$ & $3 \cdot 7$ & $5 \cdot 6$ & $4 \cdot 8$ \\
\hline
\end{tabular}

${ }^{\star}$ Appeared as a summed feature.

was determined according to the method of Norris et al. (1985); hydrolysis of chitin and Tweens 20, 40 and 80 was determined according to Baumann \& Baumann (1981). Substrate utilization patterns and other enzymic activities were tested using the commercial systems API 20E, API 20NE, API 50CH and API ZYM (bioMérieux). Cells for inoculation to the API systems were suspended in a sterile solution of seawater mixture at $22 \%$ salinity (MacDonell et al., 1982).

UST030701-295 ${ }^{\mathrm{T}}$ differs from the three previously described species of Winogradskyella on the basis of: (i) sensitivity to streptomycin and benzylpenicillin, (ii) ability to produce acetoin, (iii) ability to grow at $44^{\circ} \mathrm{C}$ and (iv) negative reaction for agar degradation (Table 2). Strain UST030701$295^{\mathrm{T}}$ can be distinguished from W. epiphytica, W. eximia and $W$. thalassocola on the basis of seven, 17 and 17 phenotypic
Table 2. Characteristics used to differentiate UST030701$295^{\top}$ from the three recognized members of the genus Winogradskyella

Taxa: 1, UST030701-295' ; 2, W. epiphytica; 3, W. eximia; 4, W. thalassocola. Data for W. epiphytica, W. eximia and W. thalassocola are taken from Nedashkovskaya et al. (2005). All are susceptible to kanamycin. All are positive for degradation of gelatin and Tween 40 and for alkaline phosphatase, catalase and oxidase activities. All are negative for nitrate reduction, $\beta$-galactosidase and urease activities, cellulose and chitin degradation, flexirubin and indole production and citrate, D-adonitol, L-arabinose, dulcitol, Dgalactose, inositol, D-lactose, D-melibiose, L-rhamnose, D-sorbitol, D-xylose and L-xylose utilization.

\begin{tabular}{|lcccc|}
\hline Characteristic & $\mathbf{1}$ & $\mathbf{2}$ & $\mathbf{3}$ & $\mathbf{4}$ \\
\hline Growth in/at: & & & & \\
NaCl $(\%)$ & $1 \cdot 0-4 \cdot 0$ & $1 \cdot 0-8 \cdot 0$ & $1 \cdot 0-5 \cdot 0$ & $1 \cdot 0-8 \cdot 0$ \\
Temperature $\left({ }^{\circ} \mathrm{C}\right)$ & $12 \cdot 0-44 \cdot 0$ & $4 \cdot 0-37 \cdot 0$ & $4 \cdot 0-33 \cdot 0$ & $4 \cdot 0-33 \cdot 0$ \\
G + C content $(\mathrm{mol} \%)$ & $32 \cdot 8$ & $35 \cdot 2$ & $36 \cdot 1$ & $34 \cdot 6$ \\
Susceptibility to: & & & & \\
Ampicillin & + & + & - & - \\
Benzylpenicillin & + & - & - & - \\
Streptomycin & + & - & - & - \\
Tetracycline & + & + & - & - \\
Production of acetoin & + & - & - & - \\
Degradation of: & & & & \\
Agar & - & + & + & + \\
Casein & - & - & + & - \\
DNA & + & + & - & - \\
Starch & - & - & + & - \\
Tween 20 & + & + & + & - \\
Tween 80 & + & + & - & - \\
Metabolism of: & & & & + \\
D-Cellobiose & - & - & - & + \\
D-Glucose & - & - & + & + \\
D-Maltose & - & - & + & + \\
D-Mannitol & - & - & + & - \\
D-Mannose & - & - & + & + \\
Sucrose & - & - & + & + \\
\hline
\end{tabular}

properties, respectively (Table 2). Molecular evidence together with phenotypic characteristics suggests that strain UST030701-295 ${ }^{\mathrm{T}}$ represents a novel species within the genus Winogradskyella.

\section{Description of Winogradskyella poriferorum sp. nov.}

Winogradskyella poriferorum (por.if.er.or'um. N.L. gen. pl. n. poriferorum of the phylum Porifera, referring to the isolation source sponge, of the phylum Porifera).

Cells are Gram-negative, rod-shaped and show rapid gliding motility. After cultivation on marine agar, colonies are yellow, circular, 2-4 $\mathrm{mm}$ in diameter, convex with a smooth surface and entire margins. Does not produce flexirubin or diffusible pigment. MK-6 is the only respiratory quinone. 
Growth of the type strain is strictly aerobic, and occurs between 12 and $44^{\circ} \mathrm{C}$ (but not at 4 or $52^{\circ} \mathrm{C}$ ) and between $\mathrm{pH} 6 \cdot 0$ and $10 \cdot 0$. Requires $\mathrm{NaCl}(1 \cdot 0-4 \cdot 0 \%)$ for growth. The $\mathrm{G}+\mathrm{C}$ content of the DNA is $32.8 \mathrm{~mol} \%$ and the predominant fatty acids are iso- $\mathrm{C}_{15: 1}$, iso- $\mathrm{C}_{15: 0}$, iso- $\mathrm{C}_{15: 0}$ $2-\mathrm{OH}$, iso- $\mathrm{C}_{15: 0} 3-\mathrm{OH}$, iso- $\mathrm{C}_{16: 0} 3-\mathrm{OH}, \mathrm{C}_{16: 1} \omega 7$ and iso$\mathrm{C}_{17: 0} 3-\mathrm{OH}$ (together representing $75 \cdot 4 \%$ of the total). Susceptible to ampicillin $(0.5 \mu \mathrm{g})$, benzylpenicillin $(0.5 \mu \mathrm{g})$, chloramphenicol $(1.0 \mu \mathrm{g})$, streptomycin $(10 \mu \mathrm{g})$ and tetracycline $(0.5 \mu \mathrm{g})$. Resistant to kanamycin (tested up to $100 \mu \mathrm{g})$. Acetoin is produced, but not indole or $\mathrm{H}_{2} \mathrm{~S}$. DNA, gelatin and Tweens 20, 40 and 80 are degraded, but agar, casein, cellulose, chitin or starch are not. Citrate is not utilized. Nitrate is not reduced. Positive for $\alpha$-chymotrypsin, catalase, cystine arylamidase, leucine arylamidase, valine arylamidase, oxidase, esterase $\left(\mathrm{C}_{4}\right)$, esterase lipase $\left(\mathrm{C}_{8}\right)$, acid phosphatase, alkaline phosphatase, lipase $\left(\mathrm{C}_{14}\right)$, naphtholAS-BI-phosphohydrolase and trypsin activity. Negative for $N$-acetyl- $\beta$-glucosaminidase, tryptophan deaminase, lysine decarboxylase, ornithine decarboxylase, arginine dihydrolase, $\alpha$-galactosidase, $\beta$-galactosidase, $\alpha$-glucosidase, $\beta$ glucosidase, $\beta$-glucuronidase, $\alpha$-fucosidase, $\alpha$-mannosidase and urease activity. Utilizes aesculin as sole carbon source, but none of the other substrates tested in the API $50 \mathrm{CH}$ system (see Supplementary Table S2 in IJSEM Online for further details).

The type strain, UST030701-295 ${ }^{\mathrm{T}}\left(=\mathrm{NRRL}\right.$ B- $41101^{\mathrm{T}}=$ JCM $12885^{\mathrm{T}}$ ), was isolated from the surface of the sponge Lissodendoryx isodictyalis in the Bahamas.

\section{Acknowledgements}

This work was supported by RGC grants HKUST6240/04M and CA04/ 05.Sc01 to P.-Y.Q. and an NSF Biological Oceanography Program grant (OCE-0095724) to J. R.P.

\section{References}

Acar, J. F. (1980). The disc susceptibility test. In Antibiotics in Laboratory and Medicine, pp. 24-54. Edited by V. Lorian. Baltimore: Williams \& Wilkins.

Baumann, P. \& Baumann, L. (1981). The marine gram-negative eubacteria: genera Photobacterium, Beneckea, Alteromonas, Pseudomonas and Alcaligenes. In The Prokaryotes, vol. 1, pp. 1302-1331. Edited by M. P. Starr, H. Stolp, H. G. Trüper, A. Balows \& H. Schlegel. Berlin: Springer.

Bernardet, J. F., Nakagawa, Y. \& Holmes, B. (2002). Proposed minimal standards for describing new taxa of the family
Flavobacteriaceae and emended description of the family. Int J Syst Evol Microbiol 52, 1049-1070.

Bowman, J. P. (2000). Description of Cellulophaga algicola sp. nov., isolated from the surfaces of Antarctic algae, and reclassification of Cytophaga uliginosa (ZoBell and Upham 1944) Reichenbach 1989 as Cellulophaga uliginosa comb. nov. Int J Syst Evol Microbiol 50, 1861-1868.

Bowman, J. P., Nichols, C. M. \& Gibson, J. A. E. (2003). Algoriphagus ratkowskyi gen. nov., sp. nov., Brumimicrobium glaciale gen. nov., sp. nov., Cryomorpha ignava gen. nov., sp. nov. and Crocinitomix catalasitica gen. nov., sp. nov., novel flavobacteria isolated from various polar habitats. Int J Syst Evol Microbiol 53, 1343-1355.

Collins, M. D. (1994). Isoprenoid quinones. In Chemical Methods in Prokaryotic Systematics, pp. 265-310. Edited by M. Goodfellow \& A. G. O'Donnell. Chichester: Wiley.

Isnansetyo, A. \& Kamei, Y. (2003). Pseudoalteromonas phenolica sp. nov., a novel marine bacterium that produces phenolic antimethicillin-resistant Staphylococcus aureus substances. Int J Syst Evol Microbiol 53, 583-588.

Ludwig, W., Strunk, O., Westram, R. \& 29 other authors (2004). ARB: a software environment for sequence data. Nucleic Acids Res 32, 1363-1371.

MacDonell, M. T., Singleton, F. L. \& Hood, M. A. (1982). Diluent composition for use of API $20 \mathrm{E}$ in characterizing marine and estuarine bacteria. Appl Environ Microbiol 44, 423-427.

Mesbah, M., Premachandran, U. \& Whitman, W. (1989). Precise measurement of the $\mathrm{G}+\mathrm{C}$ content of deoxyribonucleic acid by highperformance liquid chromatography. Int J Syst Bacteriol 39, 159-167.

Nakagawa, Y. \& Yamasato, K. (1993). Phylogenetic diversity of the genus Cytophaga revealed by $16 \mathrm{~S}$ rRNA sequencing and menaquinone analysis. J Gen Microbiol 139, 1155-1161.

Nedashkovskaya, O. I., Kim, S. B., Han, S. K. \& 9 other authors (2005). Winogradskyella thalassocola gen. nov., sp. nov., Winogradskyella epiphytica sp. nov. and Winogradskyella eximia sp. nov., marine bacteria of the family Flavobacteriaceae. Int J Syst Evol Microbiol 55, 49-55.

Neu, B., Voigt, A., Mitlohner, R. \& 7 other authors (2001). Biological cells as templates for hollow microcapsules. J Microencapsul 18, 385-395.

Norris, J. R., Ribbons, D. W. \& Varma, A. K. (editors) (1985). Methods in Microbiology, vol. 18. London: Academic Press.

Smibert, R. M. \& Krieg, N. R. (1994). Phenotypic characteristics. In Methods for General and Molecular Biology, pp. 607-654. Edited by P. Gerhardt, R.G. E. Murray, W. A. Wood \& N. R. Krieg. Washington, DC: American Society for Microbiology.

Steyn, P. L., Segers, P., Vancanneyt, M., Sandra, P., Kersters, K. \& Joubert, J. J. (1998). Classification of heparinolytic bacteria into a new genus, Pedobacter, comprising four species: Pedobacter heparinus comb. nov., Pedobacter piscium comb. nov., Pedobacter africanus sp. nov. and Pedobacter saltans sp. nov. Proposal of the family Sphingobacteriaceae fam. nov. Int J Syst Bacteriol 48, 165-177. 